\title{
ANALISIS SIMULASI KEBIJAKAN PENINGKATAN EKSPOR MANGGIS INDONESIA
}

\section{POLICIES SIMULATION ANALYSIS TO INCREASE INDONESIAN MANGOSTEEN EXPORT}

\author{
Tiara Dika Ashari $^{{ }^{*},}$ Budi Setiawan $^{2}$, Syafrial $^{2}$ \\ ${ }^{1}$ Pascasarjana, Fakultas Pertanian, Universitas Brawijaya, Jl. Veteran, Malang 65145, Indonesia \\ ${ }^{2}$ Jurusan Sosial Ekonomi, Fakultas Pertanian, Universitas Brawijaya, Jl. Veteran, Malang 65145, \\ Indonesia
}

Received: 16th October 2015; Revised: 5th November 2015; Accepted: 9th November 2015

\begin{abstract}
ABSTRAK
Manggis merupakan salah satu produk hortikultura dari Indonesia yang memiliki nilai ekonomi tinggi. Ekspor manggis dari Indonesia memiliki kendala, yaitu diantaranya adalah budidaya manggis yang tradisional dan kualitas manggis yang tidak sesuai dengan keinginan negara tujuan ekspor. Sehingga penelitian ini bertujuan untuk (1) Menganalisis faktor-faktor yang mempengaruhi kinerja ekonomi manggis Indonesia dan (2) Menganalisis alternatif kebijakan yang tepat untuk meningkatkan ekspor manggis Indonesia. Metode analisis menggunakan persamaan simultan 2SLS. Simulasi kebijakan dilakukan untuk meningkatkan ekspor manggis Indonesia, yaitu (1) Skenario perluasan areal panen manggis dan (2) Skenario subsidi pupuk. Hasil dari penelitian adalah (1) Faktor- faktor yang mempengaruhi kinerja ekonomi manggis di Indonesia adalah luas areal panen manggis, produktivitas manggis, permintaan manggis domestik, harga manggis domestik dan ekspor manggis (2) Simulasi peningkatan luas areal panen manggis dan simulasi pemberian subsidi pupuk dapat meningkatkan ekspor manggis Indonesia.
\end{abstract}

Kata kunci: Simulasi kebijakan; peningkatan ekspor manggis

\begin{abstract}
Mangosteen is one of Indonesian horticulture product which has high economic value. Mangosteen export from Indonesia has some problems, there are, the cultivation of mangosteen is still using conventional cultivation and the quality of mangosteen is not qualified in importir country. Purpose of this study are (1) Analyze factors that affect the economic performance mangosteen Indonesia and (2) Analyze policy alternatives appropriate to increase the export of Indonesian mangosteen. The analysis method using simultaneous equations 2SLS. This study is carried out simulations of policies to increase exports mangosteen, which are (1) Expansion of mangosteen harvest area and (2) Fertilizer subsidies scenario. The results of the study are (1) Factors that influence the economic performance of mangosteen in Indonesia are mangosteen harvest area, productivity of mangosteen, mangosteen domestic demand, mangosteens domestic price and export of mangosteen and (2) Expansion of mangosteen harvest area and fertilizer subsidies scenario are able to increase Indonesian mangosteen export.
\end{abstract}

Keywords: Policy simulation; increasing of mangosteen export

\section{Pendahuluan}

Menurut data dari Badan Pusat Statistik atau BPS (2015), sektor pertanian merupakan sektor penyumbang PDB ketiga terbesar di

\footnotetext{
${ }^{*}$ Penulis Korespondensi.

E-mail: tiaradkashari@gmail.com
}

Indonesia dari sembilan sektor yang ada setelah sektor industri pengolahan dan perdagangan serta sektor hotel dan restoran. Subsektor hortikultura dapat menjadi alternatif penghasil devisa yang berpotensi selain subsektor pangan. Salah satu komoditas dari subsektor hortikultura adalah buah-buahan.

Buah-buahan saat ini sudah menjadi komoditas perdagangan internasional, namun 
pangsa pasar buah-buahan Indonesia di pasaran internasional masih sangat kecil (Sunarjono 2005). Salvatore (1996) berpendapat jika terjadi peningkatan produksi suatu komoditas dalam negeri, maka hal ini dapat menyebabkan terjadinya kelebihan produksi domestik atau disebut juga dengan over supply. Kelebihan produksi domestik akan dieskpor ke negara yang kekurangan suatu komoditas tersebut, sehingga dapat dikatakan jika produksi meningkat maka akan meningkatkan juga volume eskpor suatu komoditas.

Salah satu buah yang diekspor dari Indonesia adalah manggis (Garcinia mangostana L.). Sentra penanaman manggis di Indonesia tersebar di beberapa daerah seperti Kalimantan Timur, Kalimantan Tengah, Jawa Barat (Tasikmalaya, Bogor, Ciamis dan Purwakarta), Sumatera Barat, Sumatera Utara, Riau, Jawa Timur dan Sulawesi Utara. Daerah produsen manggis terbesar di Indonesia adalah Jawa Barat sekitar 11.512 ton dan Sumatera Barat sekitar 8.474 ton (PKBT 2015). Tren volume ekspor manggis di Indonesia pada periode tahun 20032013 cenderung mengalami peningkatan (FAOSTAT, 2015).

Buah manggis dapat menjadi potensi untuk komoditas ekspor unggulan dari Indonesia jika dilihat dari perkembangan volume ekspor, sehingga perlu adanya penanganan yang baik. Produksi manggis yang diperdagangkan saat ini umumnya berkualitas rendah karena berasal dari hutan manggis atau pekarangan yang belum tersentuh teknik budidaya (Safrizal, 2014). Strategi pengembangan buah manggis harus difokuskan pada peningkatan luas tanam, luas panen, produksi dan produktivitas manggis, meningkatkan dan mempermudah ekspor manggis dan meningkatkan kesejahteraan petani (Qosim, 2013)

Tujuan dari penelitian ini adalah sebagai berikut (1) Menganalisis faktor-faktor yang mempengaruhi kinerja ekonomi manggis Indonesia dan (2) Menganalisis alternatif kebijakan yang tepat untuk meningkatkan ekspor manggis Indonesia.

\section{Metode Penelitian}

Data yang digunakan untuk menganalisis skenario kebijakan ekspor manggis Indonesia adalah dengan menggunakan data time series dari tahun 1993 hingga tahun 2013 yang diperoleh dari terbitan Badan Pusat Statistik (BPS), Kementerian Pertanian, FAOSTAT ,
International Trade Center (ITC) dan data lain yang mendukung. Data yang dikumpulkan untuk penelitian ini meliputi data luas areal panen manggis, produktivitas lahan, produksi manggis, permintaan manggis domestik, penawaran manggis, harga manggis domestik, harga manggis dunia, harga jeruk domestik, harga pupuk, konsumsi manggis domestik, jumlah penduduk Indonesia, pendapatan nasional dan jumlah ekspor manggis.

Analisis penelitian ini menggunakan model ekonometrika dengan sistem persamaan simultan yang meliputi dampak simulasi kebijakan peningkatan eskpor manggis dan analisis validasi model. Analisis dampak kebijakan peningkatan ekspor manggis dilakukan dengan menggunakan analisis persamaan luas areal panen manggis, produktivitas manggis, permintaan manggis, harga manggis domestik dan ekspor manggis yang di susun dalam model persamaan. Untuk analisis validasi model digunakan untuk dapat melihat baik tidaknya daya prediksi suatu model.

Pada penelitian ini, model terdiri dari 7 persamaan dengan total keseluruhan jumlah variabel (endogen dan predetermined) adalah 13 variabel. Menurut Gujarati (2012), suatu persamaan dapat diidentifikasi dengan 2SLS jika dilakukan dengan rumus $\mathrm{K}-\mathrm{k}>\mathrm{m}-1$. Berikut disajikan hasil perhitungan indentifikasi persamaan model pada Tabel 1.

Tabel 1. Hasil perhitungan identifikasi persamaan model (Hasil Identifikasi Model, 2015)

\begin{tabular}{|c|c|c|c|c|c|}
\hline Persamaan & $\mathbf{K}$ & $\mathbf{k}$ & $\mathbf{K}-\mathbf{k}$ & m - 1 & Hasil \\
\hline LAPM & 13 & 3 & 10 & 6 & $\begin{array}{l}\text { Over } \\
\text { identified }\end{array}$ \\
\hline PROD & 13 & 4 & 9 & 6 & $\begin{array}{l}\text { Over } \\
\text { identified }\end{array}$ \\
\hline $\mathrm{XM}$ & 13 & 4 & 9 & 6 & $\begin{array}{l}\text { Over } \\
\text { identified }\end{array}$ \\
\hline QDM & 13 & 4 & 9 & 6 & $\begin{array}{l}\text { Over } \\
\text { identified }\end{array}$ \\
\hline PDM & 13 & 4 & 9 & 6 & $\begin{array}{l}\text { Over } \\
\text { identified }\end{array}$ \\
\hline
\end{tabular}

Pada penelitian ini model yang digunakan adalah metode 2SLS karena hasil identifikasi model adalah over identified. Spesifikasi model persamaan simultan dalam penelitian ini dapat dijabarkan sebagai berikut.

1. Luas Areal Panen Manggis (LAPM) LAPM $=a_{0}+a_{1}$ PDM $+a_{2}$ PDG + $\mathrm{a}_{3} \mathrm{LAPM}_{\mathrm{t}-1}+\mathrm{u}_{1}$. 
2. Produktivitas Manggis (PROD)

PROD $=b_{0}+b_{1}$ PDM $+b_{2}$ LAPM +

$\mathrm{b}_{3} \mathrm{HP}+\mathrm{b}_{4}$ PROD $_{\mathrm{t}-1}+\mathrm{u}_{2} \ldots \ldots \ldots \ldots \ldots$

3. Produksi Manggis (QM)

$\mathrm{QM}=\mathrm{LAPM} \times \mathrm{PROD}$.

4. Penawaran Manggis Domestik (SM)

$\mathrm{SM}=\mathrm{QM}-\mathrm{XM}$

5. Permintaan Manggis Domestik (QDM)

$$
\mathrm{QDM}=\mathrm{c}_{0}+\mathrm{c}_{1} \mathrm{PDM}+\mathrm{c}_{2} \mathrm{PJG}+\mathrm{c}_{3} \mathrm{JP}+
$$

$\mathrm{c}_{4} \mathrm{I}+\mathrm{u}_{3}$

6. Harga Manggis Domestik (PDM)

$$
\mathrm{PDM}=\mathrm{d}_{0}+\mathrm{d}_{1} \mathrm{PWM}+\mathrm{d}_{2} \mathrm{SM}+
$$$$
\mathrm{d}_{3} \mathrm{QDM}+\mathrm{d}_{4} \mathrm{PDM}_{\mathrm{t}-1}+\mathrm{u}_{4}
$$

7. Ekspor Manggis (XM)

$\mathrm{XM}=\mathrm{e}_{0}+\mathrm{e}_{1} \mathrm{PWM}+\mathrm{e}_{2} \mathrm{NT}+\mathrm{e}_{3} \mathrm{QM}+$

$\mathrm{e}_{4} \mathrm{QDM}+\mathrm{u}_{5}$.

Dimana :

LAPM = Luas Areal Panen Manggis (Ha)

PROD = Produktivitas Manggis (ton/Ha)

$\mathrm{QM}=$ Produksi Manggis (ton)

$\mathrm{XM}=$ Ekspor Manggis (ton)

$\mathrm{SM}=$ Penawaran Manggis Domestik (ton)

$\mathrm{QDM}=$ Permintaan Manggis Domestik (ton)

PDM = Harga Manggis Domestik (Rupiah/ton)

PDG = Harga Jeruk Domestik (Rupiah/ton)

PJG = Harga Jeruk Domestik (Rupiah/Kg)

PWM = Harga Manggis Dunia (Dollar/ton)

$\mathrm{HP} \quad=$ Harga pupuk $(\mathrm{Rp} / \mathrm{kg})$

NT = Nilai Tukar Dollar terhadap Rupiah (Rupiah)

JP = Jumlah Penduduk Indonesia (jiwa)

I $=$ Pendapatan per Kapita Indonesia (Rupiah)

$\mathrm{a}_{0}, \mathrm{~b}_{0}, \mathrm{c}_{0}, \mathrm{~d}_{0}, \mathrm{e}_{0}=$ Intersep

$a_{1}, a_{2}, a_{3}, b_{1}, b_{2}, b_{3}, b_{4}, c_{1}$,

$\mathrm{c}_{2}, \mathrm{c}_{3}, \mathrm{c}_{4}, \mathrm{~d}_{1}, \mathrm{~d}_{2}, \mathrm{~d}_{3}, \mathrm{~d}_{4}, \mathrm{e}_{1}$,

$\mathrm{e}_{2}, \mathrm{e}_{3}, \mathrm{e}_{4} \quad=$ Koefisien Regresi

Metode yang digunakan untuk validasi model adalah root mean square error (RMSE), root mean square percent error (RMSPE) dan Theil's Inequality Coefficient (U-Theil). Setelah dilakukan validasi model maka dilakukan simulasi kebijakan untuk peningkatan ekspor manggis. Simulasi yang telah dilakukan pada penelitian Palinggi (2011) adalah simulasi penurunan tingkat suku bunga kredit investasi bank dan peningkatan tarif impor jeruk. Sedangkan simulasi yang dilakukan pada penelitian ini adalah (1) kebijakan perluasan areal panen manggis disimulasi sebesar 50\% dan (2) kebijakan pemberian subsidi pupuk disimulasi sebesar $15 \%$.

\section{Hasil dan Pembahasan}

\subsection{Perkembangan Produksi Manggis Indonesia}

Menurut (Mudjayani, 2008), buah-buah tropis Indonesia termasuk manggis, memiliki keunggulan kompetitif dan komparatif karena memiliki daya saing kuat. Selain itu, permintaan ekpsor buah manggis dari luar negeri terus meningkat tiap tahunnya. Produksi Manggis Indonesia pada rentang tahun 1993-2013 cenderung berfluktuasi. Pada tahun 1993, tercatat produksi manggis sebesar 18.738 ton per tahun.

Produksi manggis pada tahun 1998 sebesar 23.511 ton per tahun, untuk tahun 2003 sebesar 79.073 ton per tahun, pada tahun 2008 sebesar 78.674 ton per tahun dan pada tahun 2013 tercatat produksi manggis sebesar 139.602 ton per tahunnya.

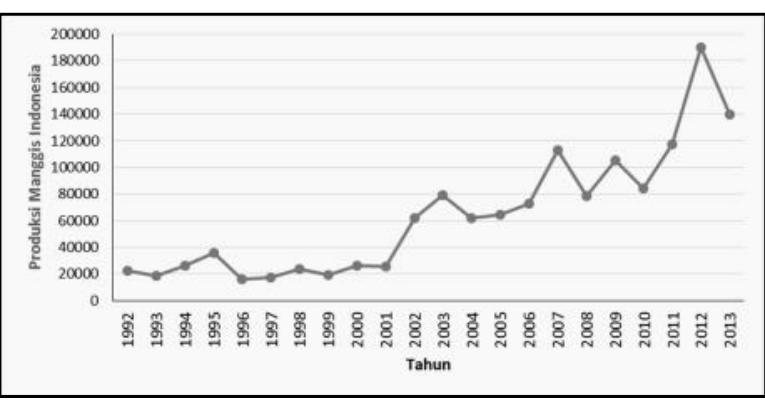

Gambar 1. Perkembangan produksi manggis Indonesia

Rata-rata produksi manggis Indonesia pada rentang tahun 1993-2013 yaitu sebesar 63.726 ton per tahun. Produksi manggis terendah terjadi pada tahun 1996 sebesar 16.288 ton, sedangkan produksi manggis tertinggi terjadi pada tahun 2012 sebesar 190.287 ton. Penurunan produksi manggis pada tahun 1996 terjadi karena adanya penurunan luas areal panen manggis menjadi 2.835 hektar dari luas areal panen sebelumnya sebesar 5.162 hektar.

\subsection{Perkembangan Luas Areal Panen Manggis}

Luas areal panen manggis di Indonesia pada rentang tahun 1993-2013 cenderung berfluktuasi dari tahun ke tahun. Pada tahun 1993 luas areal panen sebesar 3.274 hektar, pada tahun 1998 luas areal panen sebesar 5.266 hektar, pada tahun 2003 luas areal panen sebesar 9.354 hektar, selanjutnya tahun 2008 luas areal panen sebesar 
9.352 hektar dan pada tahun 2013 luas areal panen sebesar 16.022 hektar.

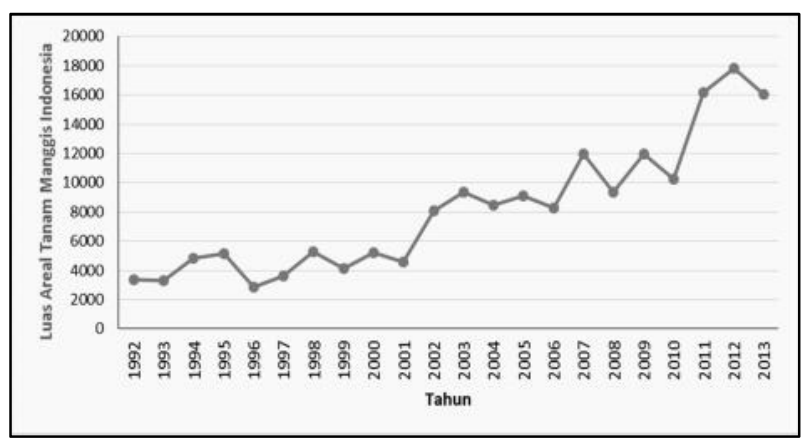

Gambar 2. Perkembangan luas areal panen manggis di Indonesia

Luas areal panen manggis Indonesia yang terendah terjadi pada tahun 1996 yaitu seluas 2.835 hektar. Sedangkan untuk luas areal panen manggis tertinggi, terjadi pada tahun 2012, yaitu sebesar 17.850 hektar dari luas panen sebelumnya seluas 16.180 hektar. Rata-rata luas areal panen manggis Indonesia pada rentang tahun 1993-2013 yaitu sebesar 8.370 ton.

\subsection{Perkembangan Produktivitas Manggis Indonesia}

Perkembangan produktivitas manggis di Indonesia pada rentang tahun 1993-2013 cenderung berfluktuasi dari tahun ke tahun. Pada tahun 1993 produktivitas sebesar 5,723 ton per hektar dan pada tahun 2003 produktivitas sebesar 9.354 ton per hektar dan pada tahun 2013 produktivitas sebesar 8,713 ton per hektar.

Produktivitas manggis masih tergolong rendah jika dibandingkan dengan Thailand. Manggis dari Indonesia yang layak ekspor hanya sekitar 20\%-30\% dari produksi, sedangkan Thailand mencapai $80 \%$. Rendahnya produktivitas manggis ini disebabkan oleh karena pengelolaan kebun manggis yang tidak baik, serta penanganan panen dan pasca panen yang masih buruk (Setiawan dkk, 2008).

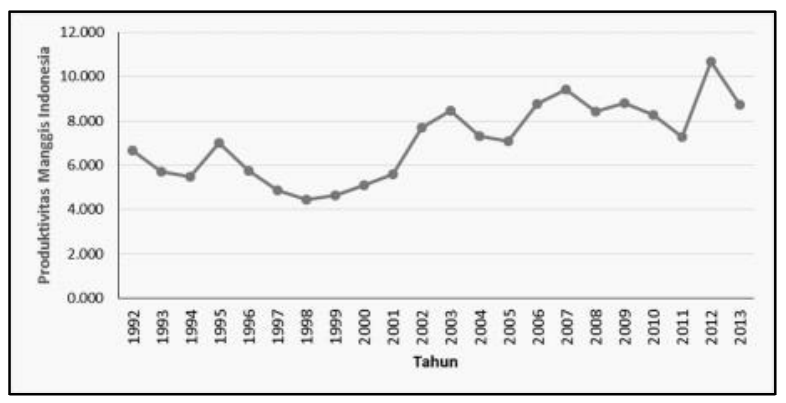

Gambar 3. Perkembangan produktivitas manggis di Indonesia
Bila produktivitas pohon-pohon manggis di sentra produksi manggis dapat ditingkatkan, maka dapat memperbesar volume ekspor dan fluktuasi ekspor manggis karena faktor musiman dapat ditekan. Hal ini memerlukan teknologi budidaya yang aplikatif dan penanganan pasca panen yang sistematis (Firdaus dkk, 2013).

\subsection{Perkembangan Permintaan Manggis Indonesia}

Pasar manggis di mancanegara maupun domestik sangat strategis sejalan dengan meningkatnya pendapatan, kesejahteraan, dan kesadaran mayarakat akan hidup sehat. Peluang pasar manggis di pasar domestik juga semakin meningkat.(Martias, 2003).

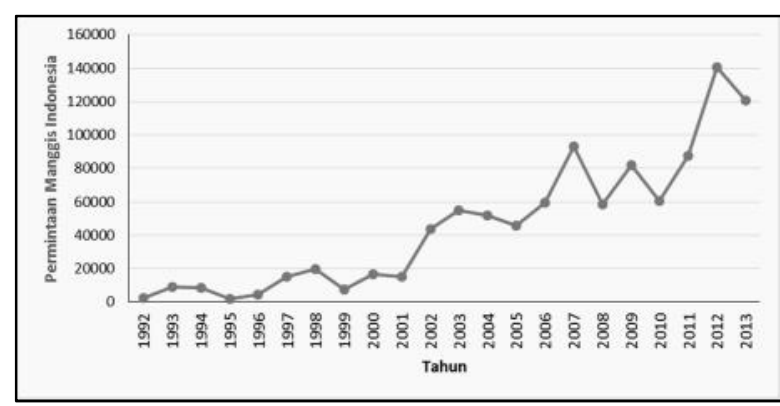

Gambar 4. Perkembangan permintaan manggis di Indonesia

Permintaan manggis di Indonesia pada rentang tahun 1993-2013 cenderung berfluktuasi dari tahun ke tahun. Pada tahun 1992 Permintaan manggis sebesar 2.541 ton, pada tahun 1998 permintaan manggis sebesar 19.664 ton, pada tahun 2003 permintaan manggis sebesar 55.036 ton, selanjutnya pada tahun 2008 permintaan manggis sebesar 58.452 ton dan pada tahun 2013 permintaan manggis sebesar 16.022 hektar.

\subsection{Perkembangan Ekspor Manggis Indonesia}

Manggis yang di ekspor merupakan produksi dari lokasi sentra seperti Kabupaten Tapanuli Selatan, Lahat, Belitung, Bogor, Tasikmalaya, Purwakarta, Purworejo, Trenggalek, Blitar dan Tabanan (Kastaman, 2007). Pada tahun 1993 eskpor manggis sebesar 4.290 ton dan pada tahun 2013 ekspor manggis sebesar 7.647 ton. Rata-rata eskpor manggis Indonesia pada rentang tahun 1993-2013 yaitu sebesar 7.853 ton per tahun. 


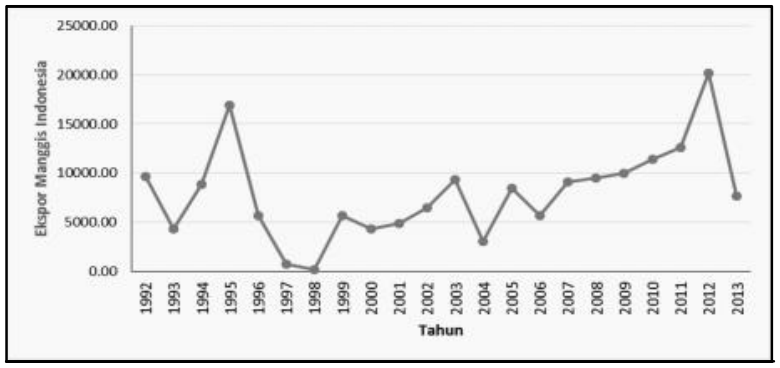

Gambar 5. Perkembangan ekspor manggis di Indonesia

Ekspor manggis tertinggi terjadi karena luas areal panen manggis pada tahun 2012 juga merupakan luas areal panen yang tertinggi sehingga mempengaruhi peningkatan produksi dan pada akhirnya mempengaruhi jumlah buah manggis yang diekspor. Volume ekspor yang fluktuatif ke negara tujuan dipengaruhi oleh kondisi dan karakteristik masing-masing negara tujuan.

\subsection{Perkembangan Harga Manggis Dunia}

Harga manggis dunia pada rentang tahun 1993-2013 cenderung mengalami kenaikan dari tahun ke tahun. Pada tahun 1993 harga manggis dunia yaitu $\mathrm{Rp} 1.647 .684,00$ per ton dan pada tahun 2013 harga manggis dunia $\mathrm{Rp}$ $12.029 .500,00$ per ton.

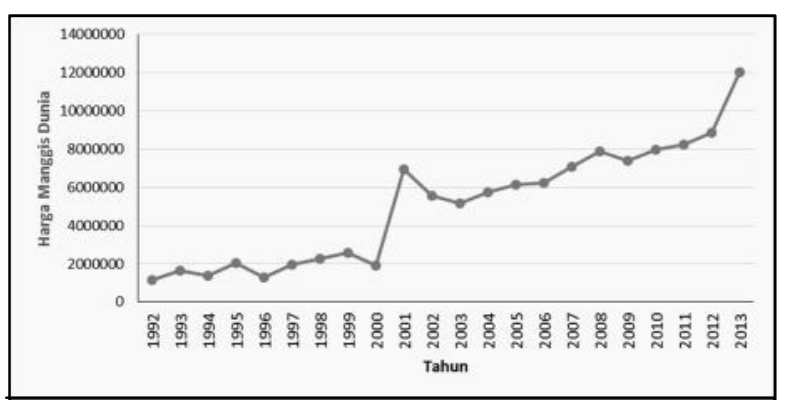

Gambar 6. Perkembangan harga manggis dunia

Harga manggis dunia yang terendah terjadi pada tahun 1996 yaitu sebesar Rp 1.274.195,00 per ton. Sedangkan untuk harga manggis dunia tertinggi, terjadi pada tahun 2013, yaitu sebesar Rp 12.029.500,00 per ton. Harga manggis dunia dapat dipengaruhi nilai tukar rupiah, jumlah penawaran manggis dan jumlah permintaan manggis dunia.

\subsection{Perkembangan Harga Manggis Domestik}

Harga manggis domestik pada rentang tahun 1993-2013 cenderung mengalami kenaikan dari tahun ke tahun. Pada tahun 1993 harga manggis domestik yaitu Rp 1.385.019 per ton dan pada tahun 2013 harga manggis domestik Rp 8.526.000,00 per ton. Rata-rata harga manggis domestik pada rentang tahun 1993-2013 yaitu sebesar Rp 3.877.794,00 per ton per tahun. Harga manggis domestik yang terendah terjadi pada tahun 1995 yaitu sebesar $\mathrm{Rp}$ 1.258.712,00 per ton.

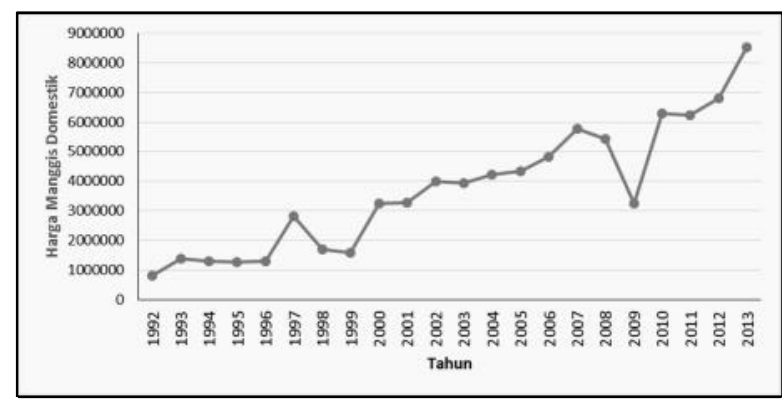

Gambar 7. Perkembangan harga manggis Indonesia

Sedangkan untuk harga manggis domestik tertinggi, terjadi pada tahun 2013, yaitu sebesar Rp 8.526.000,00 per ton.

\subsection{Faktor-faktor yang Mempengaruhi Kinerja Ekonomi Manggis Indonesia}

\subsubsection{Faktor-faktor yang Mempengaruhi Luas areal panen Manggis Indonesia}

Tabel 2. Hasil analisis 2SLS model luas areal panen manggis

\begin{tabular}{crrr}
\hline Variabel & Koefisien & t-statistik & p-value \\
\hline Konstanta & $-1696,75$ & $-2,118$ & 0,049 \\
PDM & 0,00349 & 5,026 & 0,000 \\
PDJ & 0,00147 & 1,696 & 0,108 \\
LAPMt_1 & 0,37705 & 2,210 & 0,041 \\
\hline R-square & & 0,903 & \\
F-statistik & & 43,741 & \\
p-value & & 0,000 & \\
\hline
\end{tabular}

Nilai signifikansi $\mathrm{F}$ adalah $100 \%$ pada tingkat kepercayaan $10 \%$. variabel eksogen berpengaruh secara bersama terhadap luas areal panen manggis (LAPM). Nilai koefisien determinasi $\left(\mathrm{R}^{2}\right)$ menunjukkan bahwa 90,3\% variasi luas areal panen menggis dapat dijelaskan oleh variabel eksogen, sedangkan 9,7\% variasi luas areal panen manggis dijelaskan oleh faktor lain di luar model. Pada saat nilai variabel eksogen sama dengan nol, maka luas areal panen manggis akan mengalami penurunan seluas $1.696,75 \mathrm{Ha}$. Faktor-faktor yang mempengaruhi luas areal panen manggis Indonesia adalah. 


\section{Harga Manggis Domestik}

Nilai signifikansi $\mathrm{t}$ adalah $100 \%$ yang signifikan pada taraf kesalahan sebesar $10 \%$. Apabila terjadi kenaikan harga manggis domestik sebesar 1 rupiah/ton, maka akan menyebabkan pertambahan luas areal panen manggis sebesar 0,003489 Ha.

\section{Harga Jeruk Domestik}

Harga jeruk domestik tidak berpengaruh nyata terhadap luas areal panen manggis di indonesia. Hal tersebut terlihat dari nilai signifikansi t adalah $89,2 \%$ yang tidak signifikan pada taraf kesalahan sebesar $10 \%$.

\section{Luas Areal Panen Tahun Sebelumnya}

Nilai signifikansi $\mathrm{t}$ adalah $95,9 \%$ yang signifikan pada taraf kesalahan sebesar $10 \%$. signifikan pada taraf kesalahan sebesar $10 \%$ atau tingkat kepercayaan $90 \%$. Apabila terjadi kenaikan luas areal panen manggis tahun sebelumnya sebesar 1 Ha, maka akan menyebabkan pertambahan luas areal panen manggis sebesar 0,377054 Ha. Hal tersebut disebabkan oleh karena, petani dalam menanam komoditinya tidak hanya berpedoman pada harga komoditi tahun sebelumnya dan tahun yang akan datang, namun berpedoman pula pada luas areal panen komoditi tersebut pada tahun sebelumnya (Nerlove, 1956).

\subsubsection{Faktor-faktor yang Mempengaruhi Produktivitas Manggis Indonesia}

Tabel 3. Hasil analisis 2SLS model produktivitas manggis.

\begin{tabular}{crrr}
\hline Variabel & \multicolumn{1}{c}{ Koefisien } & $\begin{array}{c}\text { t- } \\
\text { statistik }\end{array}$ & p-value \\
\hline Konstanta & $-2,649727$ & $-1,595$ & 0,090 \\
PDM & $6,03 \mathrm{E}-06$ & 2,647 & 0,018 \\
LAPM & 0,001205 & 1,774 & 0,095 \\
HP & $-0,00718$ & $-2,807$ & 0,013 \\
PROD_1 & 0,758339 & 1,828 & 0,086 \\
\hline R-square & & 0,9098 & \\
F-statistik & & 44,351 & \\
p-value & & 0,066 & \\
\hline
\end{tabular}

Nilai signifikansi $\mathrm{F}$ adalah $93,4 \%$ pada tingkat kepercayaan $10 \%$. Hal ini berarti bahwa hipotesis Ho ditolak dan hipotesis Ha diterima yaitu variabel eksogen berpengaruh secara bersama terhadap produktivitas manggis (PROD) yang meliputi harga manggis domestik (PDM), luas areal panen manggis (LAPM), harga pupuk
(HP), dan produktivitas manggis tahun sebelumnya $\left(\mathrm{PROD}_{\mathrm{t}-1}\right)$. Nilai koefisien determinasi $\left(\mathrm{R}^{2}\right)$ menunjukkan bahwa 90,98\% variasi produktivitas manggis dapat dijelaskan oleh variabel eksogen, sedangkan 9,02\% variasi produktivitas manggis dijelaskan oleh faktor lain di luar model. Pada saat nilai variabel eksogen sama dengan nol, maka produktivitas manggis akan menurun sebesar 2,649727 ton/Ha. Faktorfaktor yang mempengaruhi produktivitas manggis Indonesia adalah sebagai berikut.

\section{Harga Manggis Domestik}

Nilai signifikansi $\mathrm{t}$ adalah $98,2 \%$ yang signifikan pada taraf kesalahan sebesar $10 \%$. Apabila terjadi kenaikan harga manggis domestik sebesar 1 rupiah/ton, maka akan menyebabkan kenaikan atau pertambahan produktivitas manggis sebesar 6.03E-06 ton/Ha.

\section{Luas Areal Panen Manggis}

Nilai signifikansi $\mathrm{t}$ adalah $90,5 \%$ yang signifikan pada taraf kesalahan sebesar $10 \%$. Apabila terjadi kenaikan luas areal panen manggis sebesar $1 \mathrm{Ha}$, maka akan menyebabkan meningkatnya produktivitas manggis sebesar 0,001205 ton/Ha.

\section{Harga Pupuk}

Nilai signifikansi $\mathrm{t}$ adalah $98,7 \%$ yang signifikan pada taraf kesalahan sebesar $10 \%$. Apabila terjadi kenaikan harga pupuk sebesar 1 $\mathrm{Rp} / \mathrm{kg}$, maka akan menyebabkan penurunan produktivitas manggis sebesar 0,00718 ton/Ha.

\section{Produktivitas Manggis Tahun Sebelumnya}

Nilai signifikansi $\mathrm{t}$ adalah $91,4 \%$ yang signifikan pada taraf kesalahan sebesar $10 \%$. Apabila terjadi kenaikan produktivitas manggis tahun sebelumnya sebesar 1 ton/Ha, maka akan menyebabkan kenaikan atau pertambahan produktivitas manggis sebesar 0,758339 ton/Ha.

\subsubsection{Faktor-faktor yang Mempengaruhi Permintaan Manggis Indonesia}

Berdasarkan hasil perhitungan diperoleh bahwa nilai signifikansi $\mathrm{F}$ adalah $100 \%$. Hal ini berarti bahwa hipotesis Ho ditolak dan hipotesis Ha diterima yaitu variabel eksogen berpengaruh secara bersama-sama atau simultan terhadap permintaan manggis (QDM) yang meliputi harga manggis domestik (PDM), harga jeruk domestik (PDJ), jumlah penduduk (JP), dan pendapatan per kapita (I). 
Tabel 4. Hasil analisis 2SLS model permintaan manggis

\begin{tabular}{crrr}
\hline Variabel & Koefisien & t-statistik & p-value \\
\hline Konstanta & $-15,51491$ & $-1,410$ & 0,068 \\
PDM & $-0,026691$ & $-3,270$ & 0,005 \\
PDJ & 0,009561 & 1,159 & 0,264 \\
JP & 0,001119 & 2,208 & 0,042 \\
I & 0,001696 & 2,288 & 0,036 \\
\hline R-square & & 0,898 & \\
F-statistik & & 36,178 & \\
p-value & & 0,000 & \\
\hline Nilai & \multirow{2}{*}{ koefisien } & determinasi & $\left(\mathrm{R}^{2}\right)$
\end{tabular}

menunjukkan bahwa $89,8 \%$ variasi permintaan manggis dapat dijelaskan oleh variabel eksogen, sedangkan $10,2 \%$ variasi permintaan manggis dijelaskan oleh faktor lain di luar model. Apabila nilai variabel eksogen sama dengan nol, maka permintaan manggis adalah $-15,51491$ ton. Faktor-faktor yang mempengaruhi permintaan manggis Indonesia adalah sebagai berikut.

\section{Harga Manggis Domestik}

Nilai signifikansi $\mathrm{t}$ adalah $99,5 \%$ yang signifikan pada taraf kesalahan sebesar $10 \%$. Apabila terjadi kenaikan harga manggis domestik sebesar 1 rupiah/ton, maka akan menyebabkan penurunan permintaan manggis sebesar 0,026691 Ha.

\section{Harga Jeruk Domestik}

Harga jeruk domestik tidak berpengaruh nyata terhadap permintaan manggis di indonesia. Hal tersebut terlihat dari ilai signifikansi t adalah $73,6 \%$ yang tidak signifikan pada taraf kesalahan sebesar $10 \%$.

\section{Jumlah Penduduk}

Nilai signifikansi $\mathrm{t}$ adalah $95,8 \%$ yang signifikan pada taraf kesalahan sebesar $10 \%$. Apabila terjadi kenaikan jumlah penduduk sebesar 1 jiwa, maka akan menyebabkan kenaikan atau pertambahan permintaan manggis sebesar 0,001119 ton.

\section{Pendapatan per Kapita}

Nilai signifikansi $\mathrm{t}$ adalah $96,4 \%$ yang signifikan pada taraf kesalahan sebesar $10 \%$. Apabila terjadi kenaikan pendapatan per kapita sebesar 1 rupiah, maka akan menyebabkan kenaikan atau pertambahan permintaan manggis sebesar 0,001696 Ha.

\subsubsection{Faktor-faktor yang Mempengaruhi Harga Domestik Manggis}

Berdasarkan hasil perhitungan diperoleh nilai signifikansi $t$ adalah $98,5 \%$ yang signifikan pada taraf kesalahan sebesar $10 \%$. Hal ini berarti bahwa hipotesis Ho ditolak dan hipotesis $\mathrm{Ha}$ diterima yaitu variabel eksogen berpengaruh secara bersama-sama / simultan terhadap harga manggis domestik (PDM) yang meliputi harga manggis dunia (PWM), penawaran manggis $(\mathrm{SM})$, permintaan manggis (QDM), dan harga manggis domestik tahun sebelumnya (PDM_1).

Tabel 5. Hasil analisis 2SLS model harga manggis domestik

\begin{tabular}{crrr}
\hline Variabel & Koefisien & t-statistik & p-value \\
\hline Konstanta & 1.438 .433 & 1,478 & 0,015 \\
PWM & 0,270516 & 2,654 & 0,017 \\
SM & $-7,346696$ & $-2,520$ & 0,023 \\
QDM & 17,76507 & 1,784 & 0,093 \\
PDM_1 & $-0,076268$ & $-0,721$ & 0,482 \\
\hline R-square & & 0.957 & \\
F-statistik & & 89.143 & \\
p-value & & 0.000 & \\
\hline
\end{tabular}

Nilai koefisien determinasi (R-square) yang diperoleh menunjukkan bahwa 95,7 \% variasi harga menggis domestik dapat dijelaskan oleh variabel, sedangkan 4,3\% variasi harga manggis domestik dijelaskan oleh faktor lain di luar model. Pada saat nilai variabel eksogen sama dengan nol, maka harga manggis adalah $\mathrm{Rp}$ 1.438.433 per ton. Faktor-faktor yang mempengaruhi harga manggis Indonesia adalah sebagai berikut.

\section{Harga Manggis Dunia}

Harga manggis dunia berpengaruh positif dan signifikan terhadap harga manggis di indonesia. Hal tersebut terlihat dari Nilai signifikansi $\mathrm{t}$ adalah $98,3 \%$ yang signifikan pada taraf kesalahan sebesar $10 \%$. Apabila terjadi kenaikan harga manggis dunia sebesar Rp 1 per ton, maka akan menyebabkan kenaikan harga manggis domestik sebesar Rp 0,270516 per ton.

\section{Penawaran Manggis}

Penawaran manggis berpengaruh negatif dan signifikan terhadap harga manggis di indonesia. Hal tersebut terlihat dari nilai signifikansi $t$ adalah $97,7 \%$ yang signifikan pada taraf kesalahan sebesar $10 \%$. Apabila terjadi kenaikan penawaran manggis sebesar 1 ton, maka 
akan menyebabkan penurunan harga manggis domestik sebesar Rp 7,346696 per ton.

\section{Permintaan Manggis}

Permintaan manggis berpengaruh nyata terhadap harga manggis di indonesia. Hal tersebut terlihat dari nilai signifikansi $\mathrm{t}$ adalah 90,7\% yang signifikan pada taraf kesalahan sebesar 10\%. Apabila terjadi kenaikan permintaan manggis sebesar 1 ton, maka akan menyebabkan harga manggis domestik meningkat sebesar Rp 17,76507 per ton.

\section{Harga Manggis Domestik Tahun Sebelumnya}

Harga manggis domestik tahun sebelumnya tidak berpengaruh nyata terhadap harga manggis di indonesia. Hal tersebut terlihat dari nilai signifikansi $t$ adalah $51,8 \%$ yang tidak signifikan pada taraf kesalahan sebesar $10 \%$.

\subsubsection{Faktor-faktor yang Mempengaruhi Ekspor Manggis Indonesia}

Berdasarkan hasil perhitungan diperoleh bahwa nilai signifikansi $\mathrm{F}$ adalah $100 \%$ pada tingkat kesalahan sebesar $10 \%$. Hal ini berarti bahwa hipotesis Ho ditolak dan hipotesis $\mathrm{Ha}$ diterima yaitu variabel eksogen berpengaruh secara bersama-sama / simultan terhadap ekspor manggis (XM). Nilai koefisien determinasi (Rsquare) yang diperoleh sebesar 0.904 menunjukkan bahwa 90,4 \% variasi ekspor manggis dapat dijelaskan oleh variabel, sedangkan $9,6 \%$ variasi ekspor manggis dijelaskan oleh faktor lain di luar model.

Tabel 6. Hasil analisis 2SLS model ekspor manggis

\begin{tabular}{crrr}
\hline Variabel & \multicolumn{1}{c}{ Koefisien } & $\begin{array}{c}\text { t- } \\
\text { statistik }\end{array}$ & p-value \\
\hline Konstanta & $-11.296,17$ & $-3,964$ & 0,001 \\
PWM & 0,000486 & 1,482 & 0,158 \\
NT & 0,609841 & 2,906 & 0,010 \\
QM & 0,264703 & 4,290 & 0,001 \\
QDM & $-0,235012$ & $-2,850$ & 0,012 \\
\hline R-square & & 0,904 & \\
F-statistik & & 44.101 & \\
p-value & & 0,000 & \\
\hline
\end{tabular}

Pada saat nilai variabel eksogen sama dengan nol, maka ekspor manggis adalah $11.296,17$ ton. Faktor-faktor yang mempengaruhi ekspor manggis adalah sebagai berikut.

\section{Harga Manggis Dunia}

Harga manggis dunia tidak berpengaruh nyata terhadap ekspor manggis Indonesia. Hal tersebut terlihat nilai signifikansi t adalah $84,2 \%$ yang tidak signifikan pada taraf kesalahan sebesar $10 \%$.

2. Nilai Tukar

Nilai tukar berpengaruh nyata terhadap ekspor manggis Indonesia. Hal tersebut terlihat dari nilai signifikansi $\mathrm{t}$ adalah $99 \%$ yang signifikan pada taraf kesalahan sebesar $10 \%$. Apabila terjadi kenaikan nilai tukar rupiah terhadap dollar sebesar 1 rupiah, maka akan menyebabkan ekspor manggis menurun sebesar 0,609841 ton.

\section{Produksi Manggis}

Produksi manggis berpengaruh positif dan signifikan terhadap ekspor manggis Indonesia. Hal tersebut terlihat dari nilai signifikansi $\mathrm{t}$ adalah $99,9 \%$ yang signifikan pada taraf kesalahan sebesar $10 \%$. Apabila terjadi kenaikan produksi manggis sebesar 1 ton, maka akan menyebabkan ekspor manggis meningkat sebesar 0,264703 ton.

\section{Permintaan Manggis Domestik}

Permintaan manggis domestik berpengaruh negatif dan signifikan terhadap ekspor manggis Indonesia. Hal tersebut terlihat nilai signifikansi t adalah $98,8 \%$ yang signifikan pada taraf kesalahan sebesar $10 \%$ Apabila terjadi kenaikan permintaan manggis sebesar 1 ton, maka akan menyebabkan ekspor manggis menurun sebesar 0,235012 ton.

\subsection{Alternatif Simulasi Kebijakan Guna Memperbaiki Kinerja Perekonomian Manggis di Indonesia}

\subsubsection{Skenario Perluasan Areal Panen Manggis Indonesia}

Perubahan variabel terbesar akibat adanya perluasan areal panen manggis adalah variabel ekspor manggis sebesar 113,86\%. Hal ini disebabkan karena adanya perluasan areal panen sebesar $50 \%$ akan meningkatkan produksi manggis sebesar 22,36\%. Peningkatan produktivitas sebesar $16,55 \%$. juga terjadi setelah dilakukan perluasan areal panen manggis. 
Tabel 7. Hasil simulasi kebijakan perluasan areal panen manggis (50\%)

\begin{tabular}{ccccc}
\hline \multirow{2}{*}{ Variabel } & \multirow{2}{*}{$\begin{array}{c}\text { Nilai } \\
\text { Awal }\end{array}$} & Nilai & \multicolumn{2}{c}{ Perubahan } \\
\cline { 5 - 5 } & Simulasi & Nilai & Persentase \\
\hline LAPM & $8.398,1$ & $12.585,4$ & $4.187,3$ & $49,86 \%$ \\
PROD & 127,5 & 148,6 & 21,1 & $16,55 \%$ \\
QDM & 48.486 & $52.863,2$ & 4377,2 & $9,03 \%$ \\
PDM & 3.816 .603 & 3.427 .451 & -389152 & $-10,20 \%$ \\
XM & $7.770,9$ & $16.618,5$ & 8847,6 & $113,86 \%$ \\
QM & 388.518 & 542.994 & 154476 & $39,76 \%$ \\
SM & 11.878 .932 & 12.163 .776 & 284844 & $2,40 \%$ \\
\hline
\end{tabular}

Peningkatan produksi manggis ini akan disertai pula dengan peningkatan penawaran manggis domestik sebesar $8,29 \%$. Sesuai dengan hukum penawaran, jika penawaran bertambah maka akan menyebabkan penurunan harga suatu komoditas. Harga manggis domestik menurun sebesar $10,20 \%$ karena adanya peningkatan penawaran manggis domestik. Penurunan harga yang terjadi akan menyebabkan peningkatan jumlah permintaan manggis sebesar 9,03\%. Hal ini disebabkan karena dengan harga yang murah, maka akan semakin banyak masyarakat yang mampu untuk membeli manggis.

\subsubsection{Skenario Pemberian Subsidi Pupuk}

Tabel 8. Hasil simulasi kebijakan subsidi pupuk $(15 \%)$

\begin{tabular}{ccccc}
\hline \multirow{2}{*}{ Variabel } & \multirow{2}{*}{$\begin{array}{c}\text { Nilai } \\
\text { Awal }\end{array}$} & Nilai & \multicolumn{2}{c}{ Perubahan } \\
\cline { 5 - 5 } & Simulasi & Nilai & Persentase \\
\hline LAPM & $8.398,1$ & $8.792,8$ & 394,7 & $4,70 \%$ \\
PROD & 127,5 & 137 & 9,5 & $7,45 \%$ \\
QDM & 48.486 & $49.276,8$ & 790,8 & $1,63 \%$ \\
PDM & 3.816 .603 & 3.563 .104 & $-253,5$ & $-6,64 \%$ \\
XM & $7.770,9$ & $16.484,4$ & $8.713,5$ & $112,13 \%$ \\
QM & 388.518 & $399.875,7$ & $11.357,7$ & $2,92 \%$ \\
SM & 11.878 .932 & $12.180 .791,3$ & $301.859,3$ & $2,54 \%$ \\
\hline
\end{tabular}

Berdasarkan hasil simulasi kebijakan pemberian subsidi pupuk di Indonesia terdapat tujuh variabel endogen yang terkena dampak kebijakan subsidi pupuk. Luas areal panen meningkat sebesar 4,70\% sehingga dapat memungkinkan untuk meningkatkan produksi manggis. Produktivitas manggis meningkat sebesar 7,45\% akibat adanya kebijakan pemberian subsidi pupuk. Permintaan manggis domestik meningkat sebesar 1,63\%, yaitu menjadi sebesar 49.276,8 ton. Harga manggis domestik menurun sebesar 6,64\%. Ekspor manggis meningkat sebanyak $112,13 \%$, yaitu meningkat menjadi sebesar 16.484,4 ton. Sedangkan produksi manggis dan penawaran manggis meningkat masing-masing sebesar $21,71 \%$ dan $7,59 \%$.

\section{Kesimpulan}

Faktor- faktor yang mempengaruhi kinerja ekonomi manggis di Indonesia adalah sebagai berikut.

1. Luas areal panen manggis, dipengaruhi oleh harga manggis domestik dan luas areal panen manggis tahun sebelumnya.

2. Produktivitas manggis, harga manggis domestik, luas areal panen dan produktivitas manggis tahun sebelumnya dan produktivitas manggis.

3. Permintaan manggis domestik, dipengaruhi oleh jumlah penduduk Indonesia, pendapatan penduduk dan jumlah permintaan manggis domestik.

4. Harga manggis domestik, dipengaruhi oleh harga manggis dunia, permintaan manggis domestik dan penawaran manggis.

5. Ekspor manggis oleh produksi manggis, nilai tukar dan permintaan manggis domestik.

Berdasarkan hasil simulasi didapatkan beberapa alternatif kebijakan yang bisa digunakan untuk peningkatan ekspor manggis Indonesia adalah:

1. Simulasi peningkatan luas areal panen manggis sebesar $50 \%$ mampu meningkatkan ekspor sebesar 113,86\% atau menjadi sebanyak $16.618,5$ ton

2. Simulasi pemberian subsidi pupuk sebesar 15\% mampu meningkatkan ekspor sebesar $112,13 \%$ atau menjadi sebanyak $16.484,4$ ton.

\section{Daftar Pustaka}

[1]. Badan Pusat Statistik. (2015). Statistik Indonesia. Jakarta.

[2]. Firdaus, M., Wagiono., dan Yayah, K. (2013). Daya Saing dan Sistem Pemasaran Manggis Indonesia. Bunga Rampai Agribisnis.

[3]. Food Agricultural Organization Statistic. (2014). Ekspor Impor Negara di Dunia. Available at http://faostat3.fao.org. Diakses pada 28 Maret 2015.

[4]. Gujarati dan Damodar, N. (2012). DasarDasar Ekonometrika Buku 1. Jakarta: Penerbit Salemba Empat.

[5]. Kastaman, R. (2007). Laporan Penelitian Analisis Sistem dan Strategi Pengembangan Futuristik Pasar Komoditas Manggis Indonesia. Laboratorium Sistem 
\& Manajemen Keteknikan Pertanian Universitas Padjajaran.

[6]. Mudjayani, W. Y. (2008). Analisis Daya Saing Buah-buah Tropis Indonesia. Fakultas Ekonomi dan Manajemen Institut Pertanian Bogor. Bogor.

[7]. Nerlove, M. L. (1956). The Dynamics of Supply: Estimation of Farmers Response To Prices. The John Hopkins Press: Baltimore.

[8]. Pusat Kajian Buah Tropika. (2015). RUSNAS Buah 2015.

[9]. Safrizal. (2014). Pengaruh Pemberian Hara Fosfor Terhadap Status Hara Fosfor Jaringan, Produksi Dan Kualitas Buah Manggis (Garcinia Mangostana L.). Floratek. Fakultas Pertanian Universitas Malikussaleh. Volume 9. Nomor 1. Hal 22-28.

[10]. Salvatore, D. (1996). Ekonomi Internasional. Edisi V. Jilid I. Terjemahan. Jakarta: Erlangga.

[11]. Setiawan, E. dan Poerwanto, R. (2008). Produktivitas dan Kualitas Buah Manggis (Garcinia manggostana L.) di Purwakarta. Agrovigor. Fakultas Pertanian Universitas Trunojoyo. Volume 1. Nomor 1. Hal 1220.

[12]. Sunarjono, H. (2005). Berkebun 21 Jenis Tanaman Buah. Jakarta: Penebar Swadaya.

[13]. Qosim, W. A. (2013). Pengembangan Buah Manggis sebagai Komoditas Ekspor Indonesia. Jurnal Kultivasi. Fakultas Pertanian Universitas Padjadjaran. Volume 12. Nomor 1. Hal 40-45. 